\title{
Salmonella ishali olan immün yetmezlikli bir olguda oral immünoglobulin tedavisi
}

\section{Oral human serum immunoglobulin treatment in an immunocompromised patient with Salmonella diarrhea}

\author{
Fatma Duksal, Utku Aygüneş*, Fatih Bolat, Mehmet Burhan Oflaz, Ömer Cevit \\ Pediatri Kliniği (Dr. U. Aygüneş), Sivas Numune Hastanesi, TR-58040 Sivas, Pediatri Anabilim \\ Dalı (Dr. F. Duksal, Yrd. Doç. Dr. F. Bolat, Yrd. Doç. Dr. M. B. Oflaz, Prof. Dr. Ö. Cevit), \\ Cumhuriyet Üniversitesi Tıp Fakültesi, TR-58140 Sivas
}

\section{Özet}

Enfeksiyon ilişkili gastroenteritte en sık tanımlanan patojen virüslerden sonra salmonelladır. Salmonella'ya bağlı enfeksiyonlarda akut faz reaktanlarında artış ve ateş daha fazla görülmektedir. Salmonella enteropatojenik gram negatif basil olup lokalize enfeksiyondan sistemik enfeksiyona kadar değişen enfeksiyonlara yol açabilmektedir. En sık görülen şekli kendini sınırlayan komplike olmayan gastroenterittir. Rotavirüs ishali de Salmonella ishali gibi genel olarak kendini sınırladığ halde, bağışıklık sistemi baskılanmış hastalarda daha uzun ve ciddi seyredebilir. Daha çok rotavirüs ishallerinde yapılan çalışmalarda, verilen oral immünoglobulinin ishal süresini, semptomların şiddetini ve viral atılımı azalttığı gösterilmiştir. Salmonella ishalinde oral immünoglobilin verildiğini gösteren bir çalı̧̧maya rastlamadık. Bu sunumda bağışıklık sistemi baskılanmış bir olguda Salmonella'ya bağlı ağır ishalin oral immünoglobulin ile tedavisi tartışılmıştır.

Anahtar sözcükler: İshal, Salmonella enfeksiyonları, oral immunoglobulin

\begin{abstract}
The most frequently identified pathogen, after viral pathogens, associated with infectious gastroenteritis is Salmonella. Increase in acute-phase reactants and fever are more frequently seen due to Salmonella infection. Salmonella, which is an enteropathogenic gram-negative bacilli causes infections ranging from localized to systemic infection. The most common form of Salmonella infection is uncomplicated self-limited gastroenteritis. In general, although rotavirus diarrhea like Salmonella diarrhea is limited by itself, it may cause a long and severe diarrhea in immunosuppressed patients. In the studies which have been done more with rotavirüs diarrhea, it was seen that, oral immunoglobulin reduced the severity of symptoms and of viral excretion. We did not find a study showing given oral immünogobilin in Salmonella diarrhea. In this presentation it is discussed oral immunoglobulin treatment in an immunosuppressed patient who had severe diarrhea due to Salmonella infection.
\end{abstract}

Keywords: Diarrhea, Salmonella infections, oral immunoglobulin

Geliş tarihi/Received: 09 Mart 2013; Kabul tarihi/Accepted: 26 Ağustos 2013

\author{
*İletişim adresi: \\ Dr. Utku Aygüneş, Pediatri Kliniği, Sivas Numune Hastanesi, TR-58040 Sivas. E-posta: \\ utkuayg@gmail.com
}

\section{Giriş}

Enfeksiyon ilişkili gastroenteritte en s1k tanımlanan patojen rotavirüs, norovirüs, adenovirüs gibi virüslerden sonra Salmonella'dır [1]. Salmonella insan sağlığını etkileyen önemli bakteriyel etkenlerden olup gida kaynaklı enfeksiyonlarda rol oynayan serotipler büyük önem taşımaktadır [2]. Salmonella'ya bağlı enfeksiyonlarda akut faz 
reaktanlarında artış ve ateş daha fazla görülmektedir [1]. Salmonella enteropatojenik gram negatif basil olup lokalize enfeksiyondan sistemik enfeksiyona kadar değişen enfeksiyonlara yol açabilmektedir $[3,4]$. Bunlar sik görülen Salmonella gastroenteritinden (ishal, kramp tarzında karın ağrısı, ateş) hayatı tehdit edici ciddi antibiyotik tedavisi gerektiren enterik ateşe kadar değişebilir. Fokal enfeksiyonlar ve asemptomatik taşıyıcılar oluşabilir. En sık görülen şekli kendini sınırlayan komplike olmayan gastroenterittir [5]. Dünya genelinde y1lda 1,3 milyar insanı etkilemekte olup [6], halen özellikle gelişen ülkeler için bir halk sağlığı problemi olmaya devam etmektedir. İnsidansı toplumun sahip olduğu bazı sosyo-ekonomik parametrelerle yakından ilişkilidir [7]. Salmonella enfeksiyonları, dünya genelinde bir dağılıma sahiptir. Dünyada her yıl Salmonella'ya bağlı 16 milyon tifoid ateş, 1,3 milyon gastroenterit ve 3 milyon ölüm gerçekleşmektedir [8]. Ülkemizden bildirilen çalışmalarda en sık izole edilen suşlar Salmonella serotip Typhimurium ve Salmonella serotip Enteridis'tir. Çoğunlukla kendini sınırlayan enfeksiyonlara yol açan non-tifoidal Salmonella suşları, bağışıklık sistemi tam gelişmemiş veya baskılanmış çocuklarda, bakteriyemi ve çeşitli ekstraintestinal organ tutulumları gibi daha ağır klinik tablolarla karşımıza çıkabilmektedir [7]. Rotavirüs ishali de Salmonella ishali gibi genel olarak kendini sınırladığ1 halde, bağışıklık sistemi baskılanmış hastalarda daha uzun ve ciddi seyredebilir. Daha çok rotavirüs ishallerinde yapılan çalışmalarda, verilen oral immünoglobulinin ishal süresini, semptomların şiddetini ve viral atılımı azalttığ1 gösterilmiştir $[9,10]$.

Salmonella ishalinde oral immünoglobulin verildiğini gösteren bir çalı̧̧maya rastlamadık. $\mathrm{Bu}$ sunumda bağışıklık sistemi baskılanmış bir olguda Salmonella'ya bağlı ağır ishalin oral immünoglobulin ile tedavisi tartışılmıştır.

\section{Olgu sunumu}

İki buçuk yaşında erkek hasta acil servise $39^{\circ} \mathrm{C}$ ye varan ateş, ishal ve kusma şikayetleriyle başvurmuştur. Hasta ağır kombine immün yetmezlik nedeniyle 2 aylıktan beri takibimizde olup 3 haftada bir $400 \mathrm{mg} / \mathrm{kg}$ dozunda intravenöz immünoglobulin (IVIG) almaktadır. Hasta ayrıca kemik iliği transplantasyonu yapılması için başka bir merkezde takip altındadır. Aile hikayesinde ağır kombine immün yetmezlik nedeniyle kardeş ölüm öyküsü vardır. Geldiğinde fizik muayene bulgularında genel durum orta, bilinç açık, turgor tonus azalmış, solunum sistemi, kardiyovasküler sistem doğal, karaciğer $3 \mathrm{~cm}$ palpabl, dalak büyüklüğü yoktu. Hastanın dışkısı kötü kokulu, mukuslu, kan içermeyen sarı-yeşil nitelikte ve dışkılama sıklığı hastane yatışı sırasında günde 1520 kez olmaktaydı. Dışkı incelemesinde lökosit mevcut olup, dışkı kültüründe Salmonella üremiştir. Diğer etkenler açısından (Rotavirüs, Adenovirüs, Entamoeba histolytica, Giardia, Clostridium difficile) bakılan antijen testleri negatif bulunmuştur. Laboratuvar tetkiklerinde hiponatremi ve hipopotasemisi mevcuttu. Hastaya dışk1 kültür antibiyogramına göre uyumlu antibiyotik tedavisi, elektrolit ve sıvı defisit tedavisi başladıktan sonra genel durumunda düzelme ya da dışkılama sayısı ve miktarında azalma olmadı. Antibiyotik, destek ve sıvı tedavisinin 5'inci gününde dışkılama sayısı günde 1520 'nin altına düşmeyen hastaya aileden izin alınarak ağız yoluyla tek doz $300 \mathrm{mg} / \mathrm{kg}$ serum immünoglobulini (Flebogamma Grifols U.S) $\% 5$ dektroz içerisinde $50 \mathrm{mg} / \mathrm{mL}$ konsantrasyonda uygulandı. Oral immünoglobulin uygulandıktan 24-48 saat sonra günlük dışkılama sıklığı hızla azalarak ikiye düşen hastanın 4'üncü günde dışkı kıvamı ve dışkılama sayısı normale döndü. Oral immünoglobulin uygulanmasının 5 'inci gününde bakılan dışkı kültürü de negatifti. Hastada herhangi bir yan etki görülmedi.

\section{Tartışma}

Primer immün yetmezlikler, immün sistemin bir ya da daha fazla bileşeninin eksik ya da işlev göremez olduğu bir grup genetik hastalıktır [11]. Ağır kombine immün yetmezlik nadir görülen konjenital bir hastalık olup insidansı 1/50 000-100 000'dir. Bozulmuş T ve B hücre fonksiyonları sonucu hayatın ilk yılında tekrarlayan ağır enfeksiyonlar (ishal, 
pnömoni, otit, sepsis, kutanöz enfeksiyonlar) ile karekterizedir [12-14]. Bağışıklığı baskılanmış bu tür hastalarda akut ya da kronik ishal sık görülen bir komplikasyondur. Kısa sürede etkin tedavi vermek mortalite, morbidite ve bulaşıcılığın önlenmesi açısından önemlidir [14].

Salmonella enfeksiyonunda hücresel immünite önemli bir rol oynamaktadır. Kazanılmış immün yetmezliği olan hastalarda, HIV enfeksiyonu olan hastalarda, bağışıklık sistemini bask1layıc1 tedavi alanlarda, lenfoproliferatif ve organ transplantasyonlu hastalarda bağışıklık sistemi normal olan hastalara göre uygun antibiyotik tedavisine rağmen, Salmonella enfeksiyonuna bağlı ağır ishal, kolit, bakteriyemi, yaygın enfeksiyon tablosu ve relaps daha sik görülmektedir $[15,16]$. Bu bulgu, hücresel immünitenin Salmonella invazyonuna karşı önemli olduğunu göstermektedir [17].

Salmonella enfeksiyonunun prognozu bakteri yükü ve konak faktörlerine bağlıdır. Konak, invaziv Salmonella enfeksiyonuna karşı yeterli miktarda immün cevap oluşturmalıdır [18]. Barsaktaki sekretuar immün globulin A (sIgA), patojenik mikroorganizmaların invazyon ve kolonizasyonuna karşı mukozal yüzeyleri korumakta temel rol oynar [19, 20]. Fare çalışmalarında sIgA'nın invaziv Salmonella enfeksiyonuna karşı koruyucu olduğu gösterilmiştir [21]. Salmonella enteritis kümes hayvanlarının ince barsaklarında kolonize olarak bulunmaktadır. Kümes hayvanlarında yapılan bir çalışmada Salmonella enteritise özgü yolk immünoglobulin hayvanların yemlerine katılmış ve koruyucu etkisi gözlenmiştir. $\mathrm{Bu}$ çalışmada immünoglobulin verilen grupta Salmonella enteritisin çekumda kolonizasyonunun ve dışkıda atılımının azaldığı gösterilmiştir [22]. Ayrıca tifolu hasta ve sağlıklı insanlarda oral tifo aşısı sonrası Salmonella'ya karşı spesik IgA antikoru ile birlikte kanda $\operatorname{IgA}, \operatorname{IgG}, \operatorname{IgM}$ ve hücresel immünite saptanmıştır [23, 24]. Bunlar Salmonella enfeksiyonunda immünitenin ne kadar önemli olduğunu göstermektedir.

Bağışıklığı baskılanmamış normal çocuklarda ağır rotavirüs ishalinde $300 \mathrm{mg} / \mathrm{kg}$ dozunda immünoglobulin verildikten sonra daha çabuk iyileşme tespit edilmiş ve hastalarda herhangi bir yan etki olmadan hastaneden daha çabuk taburcu edilmiştir [10]. Aynı tedavi ağır rotavirüs ishali olan AIDS hastalarına da uygulanmış ve benzer etkiler görülmüştür [25]. Yine aynı şekilde gastroenteriti olan 71 çocukta yapılan çalışmada immünoglobulin alan grupta klinik durumda düzelme ve ishal sayısında azalma almayanlara göre daha hızlı olmuştur [10]. Başka bir çalışmada bağışıklığ rotavirüs ishalinde $300 \mathrm{mg} / \mathrm{kg}$ serum immünoglobulini ( $\% 5$ dektroz içerisinde $50 \mathrm{mg} / \mathrm{mL}$ konsantrasyonda) uygulandıktan sonra hastaların kliniğinde düzelme ve dışkılama sayısında belirgin azalma gözlenmiştir [9].

Hastamız primer immün yetmezlik olup, oral immünoglobulin uygulanmadan önce ishal ve kusma nedeniyle ciddi derecede sıvı kaybı mevcuttu ve hasta düşkün görünümdeydi. Oral immünoglobulin uygulanması sonrası 24-48 saatlik süre içinde hastanın ishal sayısı ikiye düştü ve dışkı kültürü normale döndü. Sonrasında hastanın genel durumunda ve oral alımında belirgin düzelme oldu. Tedavi sonrasında hastada herhangi bir yan etki görülmedi.

Sonuç olarak; bağışıklı̆̆ı baskılanmış hastalarda ağır Salmonella ishalinde oral immünoglobulin verilmesi bakteri yükünü ve böylece Salmonella'nın dışkıda atılımını azaltarak semptomların süresini azaltabilir. Fakat oral immünoglobulinin etkinliğini görmek için daha fazla vaka sayısı olan çalışmalara ihtiyaç vardır.

Bu makale poster olarak 1-4 Kasım 2011 tarihinde Antalya'da gerçekleştirilen "Türkiye Ulusal Allerji ve Klinik İmmünoloji Derneği Kongresi”nde sunulmuştur. 


\section{Kaynaklar}

1. Weigering V, Kaiser J, Tapped D, Weissbuch B, Morbach H, Girschick HJ. Gastroenteritis in childhood: A retrospective study of 650 hospitalized pediatric patients. Int J Infect Dis 2011; 15: 401-7.

2. Erol I. Zoonotic importance of salmonella infections. Turkiye Klinikleri J Vet Sci 2010; 1: 105-13.

3. Kaistha N, Gupta V, Sidhu S, Chander J. Salmonella-salmonellosis-rare presentations of a common pathogen. Asian Pac J Trop Med 2011; 4: 417-20.

4. Akcelik M, Akkoc N. Molecular mechanisms of salmonella pathogenicity: Review. Turkiye Klinikleri J Med Sci 2010; 30: 312-22.

5. Casadesus J. Salmonella: From basic science to clinical issues. Future microbiol 2011; 6: 133-5.

6. McGhie EJ, Brawn LC, Hume PJ, Humphreys D, Koronakis V. Salmonella takes control-driven manipulation of the host. Curr Opin Microbiol 2009; 12: 117-24.

7. Ozen M, Celiloglu C. (Salmonella infections in childhood). Turkiye Klinikleri J Pediatr Sci 2007; 3: 12-7.

8. Sireli UT. (An overwiev and regulations about salmonella infections). Turkiye Klinikleri J Vet Sci 2010; 1: 114-20.

9. Toprak D, Soysal A, Türel O, Bakır M. (Oral human serum immunoglobulin in rotavirüs diarrhea: Two case reports). Cocuk Enf Derg 2007; 1: 115-7.

10. Guarino A, Canani RB, Russo S, Albano F, Canani MB, Ruggeri FM, Donelli G, Rubino A. Oral immunoglobulins for treatment of acute rotaviral gastroenteritis. Pediatrics 1994; 93: 12-6.

11. Makay M, Olmez D, Unsal E, Anal O. Common variable immunodeficiency mimicking systemic-onset juvenile idiopathic arthritis: Differential diagnosis. Turkiye Klinikleri J Med Sci 2009; 29: 775-7.

12. Bakare N, Menschik D, Tiernan R, Hua W, Martin D. Severe combined immunodeficiency (SCID) and rotavirus vaccination: Reports to the Vaccine Adverse Events Reporting System (VAERS). Vaccine 2010; 28: 6609-12.

13. Buckley HR. Primary cellular immunodeficiencies. J Allergy Clin Immunol 2002; 109: 747-57.

14. Trevino M, Prieto E, Penalver D, Aguilera A, Garcia-Zarate A, GarciaRiestra C, Regueiro BJ. Diarrhea caused by adenovirus and astrovirus in hospitalized immunodeficient patients. Enferm Infecc Microbiol Clin 2001; 19: 7-10.

15. Jacobs JL, Gold JW, Murray HW, Roberts RB, Armstrong D. Salmonella infections in patients with the acquired immunodeficiency syndrome. Ann Intern Med 1985; 102: 186-8.

16. Gotuzzo E, Frisancho O, Sanchez J, Liendo G, Carrillo C, Black RE, Morris JG Jr. Association between the acquired immunodeficiency syndrome and infection with salmonella typhi or salmonella paratyphi in an endemic typhoid area. Arch Intern Med 1991; 151: 381-2.

17. Shimoni Z, Pitlik S, Leibovici L, Samra Z, Konigsberger H, Drucker M, Agmon V Ashkenazi S, Weinberger M. Nontyphoid salmonella bacteremia: Age-related differences in clinical presentation, bacteriology, and outcome. Clin. Infect. Dis 1999; 28: 822-7.

18. Coon C, Beagley KW, Bao S. The role of granulocyte macrophage-colony stimulating factor in gastrointestinal immunity to salmonellosis. Scand $\mathbf{J}$ Immunol 2009; 70: 106-15.

19. Brandtzaeg, P. Role of secretory antibodies in the defence against infections. Int. J. Med. Microbiol 2003; 293: 3-15.

20. Martinoli C, Chiavelli A, Rescigno M. Entry route of salmonella typhimurium directs the type of induced immune response. Immunity 2007; 


\section{7: 975-84.}

21. Michetti P, Mahan MJ, Slauch JM, Mekalanos JJ, Neutra MR. Monoclonal secretory immunoglobulin A protects mice against oral challenge with the invasive pathogen salmonella typhimurium. Infect Immun 1992; 60: 1786-92.

22. Rahimi S, Shiraz ZM, Salehi TZ, Torshizi MAK, Grimes JL. Prevention of salmonella infection in poultry by specific egg-derived antibody. Int. J. Poult Sci. 2007; 6: 230-5.

23. Kantele A,Arvilommi H, Jokinen I. Specific immunoglobulin-secreting human blood cells after peroral vaccination against Salmonella typhi. J. Infect. Dis 1986; 153: 1126-31.

24. Cancellieri V, Fara GM. Demonstration of specific IgA in human feces after immunization with live Ty2la salmonella typhi vaccine. J. Infect. Dis 1985; 151: 482-4.

25. Guarino A, Albano F, Canani RB, Bruzzese E. HIV, fatal rotavirus infection, and treatment options. The Lancet 2002; 359: 74. 